\title{
Assessment of quality of life among women with polycystic ovary syndrome of different reproductive age
}

\author{
L. V. Pakharenko*, V. D. Vorobii, N. Ya. Kurtash, O. M. Perkhulyn
}

State Higher Educational Establishment “Ivano-Frankivsk National Medical University”, Ukraine

Key words: polycystic ovary syndrome, age groups, quality of life.

\section{Zaporozhye} medical journal 2019; 21 (1), 100-103

DOl:

10.14739/2310-1210

2019.1.155842

*E-mail: ludapak@ukr.net
Polycystic ovary syndrome (PCOS) is one of the most problematic neuroendocrine syndromes in gynecology. It affects $6-25 \%$ of reproductive-age women.

Aim of research. To assess the quality of life in women with PCOS in early and active reproductive age.

Materials and methods. The basic group consisted of 90 women with PCOS and was divided into the I and II subgroups. 60 women aged 18-25 years formed the I subgroup, 30 patients aged 26-35 years - the II one. 30 women without this pathology were controls. Diagnosis of PCOS was based on the Rotterdam criteria. Quality of life was assessed with the help of the 36-Item Short Form Health Survey.

Results. The parameters of quality of life physical component in women of the basic group were slightly less than in controls. Statistically significant difference was determined only in persons of the II subgroup on the "Physical Functioning" and "General Health" scores by $11.59 \%(P=0.039)$ and $15.98 \%(P=0.026)$ lower, respectively, compared to controls. More pronounces and significant decrease in quality of life was found in parameters of the psychological component, especially the "Vitality" and "Social functioning" scores were by $16.51 \%(P=0.021)$ and $23.12 \%(P<0.001)$ lower, respectively, compared to healthy women. The overall scores of quality of life were lower in persons of the II subgroup than in I.

Conclusions. Decrease in quality of life is typical for women with PCOS. No significant difference was detected in the physical component score of quality of life between persons with PCOS and controls in the early reproductive age. Though, "Physical Functioning" and "General Health" scores were statistically lower in patients of active reproductive age compared to healthy individuals. However, a decrease in the psychological component of quality of life is typical for women with PCOS, especially for persons of the active reproductive age compared to those of the early one.
Киючові слова: СИнАРОМ полікистозних яєчників, вік, якість життя.

Запорізький медичний журнал. - 2019. T. 21, № 1(112). C. $100-103$

\section{Оцінювання якості життя жінок різного репродуктивного віку з синдромом полікістозних яєчників}

\section{А. В. Пахаренко, В. А. Воробій, Н. Я. Курташ, О. М. Перхулин}

Синдром полікістозних яєчників (СПКЯ) - один із найбільш проблемних нейроендокринних синдромів у гінекології. Його виявляють у $6-25 \%$ жінок репродуктивного віку.

Мета роботи - оцінити якість життя жінок із СПКЯ в активному та ранньому репродуктивному віці.

Матеріали та методи. 90 жінок із СПКЯ увійшли в основну групу, що складалася з li Il підгруп. 60 жінок віком 18-25 років утворили I підгрупу, 30 пацієнток віком 26-35 років - II підгрупу. Контрольна група включала 30 жінок без цієї патології. Діагноз СПКЯ ґрунтувався на критеріях, що запропоновані Роттердамським консенсусом. Якість життя вивчали за допомогою опитувальника SF-36.

Результати. Параметри фізичного компонента якості життя в жінок в основній групі були дещо меншими, ніж у контрольній. Статистично значуща відмінність визначена тільки в осіб II підгрупи порівняно з контролем за шкалами «Фізичне функціонування» - на 11,59 \% менше ( $p=0,039)$, «Загальний стан здоров'я» - на 15,98 \% ( $p=0,026)$. Більш виражене зниження констатувади щодо шкал психологічного компонента. Особливо відзначили зменшення показників шкал «Життєва активність» - на 16,51 \% ( $p=0,021)$, «Соціальне функціонування» - на 23,12 \% ( $<0,001)$ порівняно зі здоровими жінками. Значення всіх параметрів шкал були меншими в осіб II підгрупи порівняно 3 I.

Висновки. Зниження якості життя характерне для хворих із СПКЯ. Не виявили значущу різницю за показниками фізичного компонента якості життя жінок із СПКЯ у ранньому репродуктивному віці та контролі. Параметри шкал «Фізичне функціонування» та «Загальний стан здоров'я» були статистично нижчі в осіб із СПКЯ в активному репродуктивному віці порівняно зі здоровими жінками. Але зниження психологічної складової якості життя характерне для пацієнтів із СПКЯ, особливо для жінок активного репродуктивного віку порівняно з раннім.
Ключевые слова: СИнаром поликистозных яичников, возраст, качество жизни.

Запорожский медицинский журнал. - 2019. T. 21, № 1(112). C. 100-103

\section{Оценка качества жизни женщин разного репродуктивного возраста с синдромом поликистозных яичников}

\section{А. В. Пахаренко, В. А. Воробий, Н. Я. Курташ, О. М. Перхулин}

Синдром поликистозных яичников (СПКЯ) - один из наиболее проблемных нейроэндокринных синдромов в гинекологии. Его диагностируют у 6-25\% женщин репродуктивного возраста.

Цель работы. Оценить качество жизни женщин с СПКЯ в раннем и активном репродуктивном возрасте.

Материалы и методы. 90 женщин с СПКЯ вошли в основную группу, которая состояла из I и II подгрупп. 60 женщин 18-25 лет составили I подгруппу, 30 пациенток в возрасте 26-35 лет - II подгруппу. Контрольная группа включала 30 женщин 
без данной патологии. Диагноз СПКЯ основан на критериях, предложенных Роттердамским консенсусом. Качество жизни изучали с помощью опросника SF-36.

Результаты. Параметры физического компонента качества жизни у женщин основной группы были немного меньшими, чем в контроле. Статистически значимое различие определили только у лиц II подгруппы по сравнению с контролем по шкалам «Физическое фрункционирование» - на 11,59\% меньше $(p=0,039)$, «Общее состояние здоровья» - на $15,98 \%$ ( $=0$, 026). Более выраженное снижение констатировано относительно шкал психологического компонента. Особенно отмечено уменьшение показателей шкал «Жизненная активность» - на 16,51 \% ( $=$ = 0,021), «Социальное фуункционирование» - на 23,12\% ( $p<0,001)$ по сравнению со здоровыми женщинами. Значения всех параметров шкал были меньше у лиц II подгруппы по сравнению с I.

Выводы. Снижение качества жизни характерно для больных с СПКЯ. Не установили существенную разницу в показателях физического компонента качества жизни женщин с СПКЯ в раннем репродуктивном возрасте и контроле. Параметры шкал «Физическое функционирование» и «Общее состояние здоровья» были статистически ниже у лиц с СПКЯ в активном репродуктивном возрасте по сравнению со здоровыми женщинами. Тем не менее, снижение психологической составляющей качества жизни характерно для пациенток с СПКЯ, особенно для женщин активного репродуктивного возраста по сравнению с ранним.

Polycystic ovary syndrome (PCOS) is one of the most problematic neuroendocrine syndromes in gynecology. It affects $6-25 \%$ of reproductive-age women [1]. Combination of hormonal problems, morphological changes of ovarian structures, metabolic disorders usually accompany patients with this neuroendocrine syndrome [2]. Such disorders influence many parameters of woman's life. Menstrual cycle dysregulation (amenorrhea, oligomenorrhea) is the most common complaint among PCOS patients and the reason for seeking gynecological care. Increased body weight, hirsutism are visual signs of this neuroendocrine syndrome which are ignored by most of the women with PCOS. Such abnormalities as impaired glucose tolerance and possible diabetes mellitus are frequently developed [3]. Few persons consult a doctor at the onset of diseases when they are adolescence. Most of the patients visit a gynecologist in adulthood exactly with infertility problem when they are going to be pregnant and the fertilization attempts were unsuccessful for more than 1-2 years.

All the above mentioned indicates that PCOS greatly influence the psychological status of women and their quality of life [4,5]. Depressive or aggressive behavior is typical for such patients [6] and can be associated with hyperandrogenia [7] as well as with all above mentioned complaints.

\section{Aim}

To assess the quality of life in women with PCOS in early and active reproductive age.

\section{Materials and methods}

Diagnosis of PCOS was based on the Rotterdam criteria with the presence of two or three of the following ones: polycystic ovaries (at least 12 or more follicles or increased ovarian volume more than $10 \mathrm{~cm}^{3}$ ), oligo-ovulation or anovulation and clinical and/or biochemical signs of hyperandrogenism [8]. The basic group consisted of 90 women with PCOS and was divided into the I and II subgroups. 60 women aged 18-25 years formed the I subgroup, 30 patients aged 26-35 years - the II one. 30 women without this pathology were controls. Inclusion criteria: presence of PCOS, age range 18-35 years, written informed consent from the patient. Exclusion criteria: alimentary obesity, congenital adrenal hyperplasia, hyperprolactinemia, Cushing's syndrome, acromegaly, hormone producing tumors of ovaries and adrenal glands, thyroid gland diseases.
Ultrasound examination of pelvic organs was conducted with apparatus Voluson 730 Pro using 3.5 and $7.5 \mathrm{MHz}$ transducers. Luteinizing hormone, follicle-stimulating hormone, estradiol, prolactin, free testosterone, dehydroepiandrosterone sulfate were measured with standard sets of reagents "XEMA" (RF), serum anti-Mullerian hormone and cortisol were determined using reagents "Beckman Coulter Company" (USA) on the 5-6 $6^{\text {th }}$ days of menstrual cycle, progesterone (set "XEMA" (RF)) - on the $18^{\text {th }}-22^{\text {d }}$ days using an absorbance microplate reader (Tecan Sunrise). Also we determined blood glucose level, amount of insulin, lipoproteins. Quality of life was studied with the help of the 36-Item Short Form Health Survey (SF-36).

Statistica 6.0 software package was used for statistical analysis. Descriptive statistics (mean, standard error of mean), nonparametric statistics (Mann-Whitney test for comparison between two independent samples) and $X^{2}$-criterion were calculated. Differences with $p$-values of less than 0.05 were considered statistically significant.

\section{Results}

The average age of the basic group patients was $24.33 \pm 0.46$ years $(21.98 \pm 0.33$ years in the I subgroup, $29.03 \pm 0.59$ - in II), in the control one $-24.87 \pm 1.03$ years. Body mass index (BMI) was $14.73 \%$ higher in persons with PCOS $(25.94 \pm 0.55)$ compared to the healthy individuals $(22.61 \pm 0.59, P=0.001)$. Such difference was attributable mainly to the II subgroup women. Thus, this difference was statistically significantly higher by $25.87 \%$ $(28.46 \pm 0.94, P<0.001)$ in the II subgroup. BMI was only $9.15 \%$ higher in the I subgroup compared to the healthy persons $(24.68 \pm 0.63, P=0.055)$.

Most women in the control group had normal BMI -25 $(83.34 \%), 4(13.33 \%)$ individuals were overweight, and 1 $(3.33 \%)$ was class I obese. Only $49(54.45 \%)$ patients with PCOS were normal-weight $\left(X^{2}=6.77, P=0.009\right), 21$ persons $(23.33 \%)$ were overweight and $20\left(22.22 \% ; X^{2}=4.33\right.$, $\mathrm{P}=0.037)$ were obese $(12(13.33 \%)$ - class I obese, 7 $(7.78 \%)$ - class II, $1(1.11 \%)$ - class III). But these indices did not show statistically significant difference between the I subgroup ((40 (66.67\%) patients had normal BMI, 11 $(18.33 \%)$-were overweight and $9(15.00 \%)$ persons were obese (class I - 5 women (8.33 \%) and 4 (6.67 \%) - class II)) and healthy women. In the II subgroup only one third of individuals had normal weight (9 $\left(30.00 \% ; X^{2}=15.27\right.$, $\mathrm{P}<0.001), 10$ (33.33\%) were overweight and 11 (36.67\%; 
Table 1. Quality of life of women with polycystic ovary syndrome (SF-36 survey)

\begin{tabular}{|c|c|c|c|c|}
\hline Score & Control group $(n=30)$ & I subgroup ( $n=60$ ) & II subgroup ( $n=30$ ) & Basic group $(n=90)$ \\
\hline Bodily pain & $79.17 \pm 4.75$ & $74.68 \pm 3.12$ & $73.63 \pm 4.94$ & $74.33 \pm 2.64$ \\
\hline Physical Functioning & $82.00 \pm 3.71$ & $77.08 \pm 2.74$ & $72.50 \pm 3.59^{*}$ & $75.56 \pm 2.19$ \\
\hline Role-Physical Functioning & $75.83 \pm 4.87$ & $66.25 \pm 3.93$ & $64.17 \pm 5.18$ & $65.56 \pm 3.12$ \\
\hline General Health & $76.33 \pm 3.45$ & $68.05 \pm 3.30$ & $64.13 \pm 3.72^{*}$ & $68.05 \pm 3.29$ \\
\hline Vitality & $79.00 \pm 3.32$ & $67.02 \pm 3.24^{*}$ & $63.83 \pm 4.64^{*}$ & $65.96 \pm 2.65^{\star}$ \\
\hline Social Functioning & $80.93 \pm 3.68$ & $66.25 \pm 3.46^{*}$ & $58.77 \pm 4.22^{*}$ & $62.22 \pm 2.80^{*}$ \\
\hline Role-Emotional Functioning & $81.33 \pm 4.31$ & $72.20 \pm 3.07$ & $66.13 \pm 5.18^{*}$ & $70.18 \pm 2.68^{*}$ \\
\hline Mental Health & $83.33 \pm 3.82$ & $73.70 \pm 3.31$ & $69.33 \pm 4.51^{*}$ & $72.24 \pm 2.66^{*}$ \\
\hline
\end{tabular}

*: a significant difference between indicators of the study and control groups $(P<0.05)$.

$\left.X^{2}=8.44, P=0.004\right)$ were obese (class I- $7(23.34 \%)$ persons, II $-3(10.00 \%)$, III - $1(3.33 \%))$.

The age at menarche was later in individuals with PCOS (14.43 \pm 0.14 years) than in the healthy women (13.03 \pm 0.17 years, $p<0.001)$. In the I and II subgroups this index was equal $(14.42 \pm 0.17$ and $14.47 \pm 0.26$ years, respectively).

The main complaint of the basic group patients was irregular menses with which they decided to visit a doctor. Women of the I subgroup had prolonged delay of menstruations for a period from 3 to 6 months in anamnesis. In addition, all persons had oligomenorrhea, 17 (28.33 \%) amenorrhea. But 17 (56.67\%) women of the II subgroup besides disorders of the menstrual cycle consulted a gynecologist also because of infertility. We believe that active reproductive-age women make a conscious decision to become pregnant unlike women in early adulthood. That is why in the II subgroup a significant part of women consulted a gynecologist because of this problem. All women of the control group had regular menstrual cycle.

Parameters of reproductive anamnesis were not statistically different between persons of two observed groups. Thus, $16(53.33 \%)$ of controls had never been pregnant and $14(46.67 \%)$ of them had pregnancies in anamnesis. In the basic group these indices were $53(58.89 \%)$ and 37 (41.11\%), respectively, (in the I subgroup - $39(65.00 \%)$ and $21(35.00 \%)$, in II - 14 (46.67\%) and 16 (53.33\%), respectively). But infertility (primary or secondary) had 4 $(13.33 \%)$ healthy persons and $31\left(34.44 \%, x^{2}=3.89\right.$, $\mathrm{P}=0.049)$ patients with PCOS $(14(23.33 \%)$ in the I subgroup and $17(56.57 \%)$ - in II $\left.\left(X^{2}=10.55, P=0.001\right)\right)$. Other observed patients who had never been pregnant did not have desire for childbirth and prevented pregnancy.

Clinical signs of hyperandrogenia (acne, male pattern hair growth on pubic area, face, hirsutism) had most of women in the basic group - 55 (61.11\%) ((41 (68.33\% and 14 $(46.67 \%)$ in the I and II subgroups, respectively). However, laboratory increase in androgens (free testosterone, cortisol, dehydroepiandrosterone sulfate) was determined only in 23 (25.56 \%) persons: (11 (18.33\%) patients in the I subgroup and $12(40.00 \%)$ in $\mathrm{I} ; \mathrm{X}^{2}=3.86, \mathrm{P}=0.049$ between the I and II subgroups). We founded that not all persons with PCOS had increased luteinizing hormone/follicle-stimulating hormone ratio more than 2.5 - only $59(65.56 \%)$ individuals (37 (61.67\%) and $22(73.33 \%)$, respectively). But the serum amount of anti-mullerian hormone was high in all patients of the basic group. Ultrasound changes of ovarian tissue indicating PCOS were determined in all women of the basic group.

As it has been mentioned, $41(45.56 \%)$ women had increased BMI versus $5(16.67 \%)$ controls $\left(X^{2}=6.77\right.$,
$P=0.009)$. Such index was attributable mainly to the amount of persons in the II subgroup (21 (70.00\%) individuals $\left(X^{2}=15.27, P<0.001\right)$, in I $-20(33.33 \%)$ women $\left.\left(X^{2}=2.00, P=0.16\right)\right)$. The other metabolic disorders such as insulin resistance, impaired glucose tolerance and lipid metabolism disorders were found only in 11 (18.33\%) persons with PCOS in early reproductive age and 17 $(56.67 \%)$ - in active one $\left(X^{2}=11.98, P<0.001\right.$ between the I and II subgroups). In the control group all individuals had normal hormonal levels and normal structure of ovaries according to echography.

Analyzing the results of quality of life we determined that SF-36 scores were lower in patients with PCOS than in healthy women (Table 1). Besides this, all the indices were worse in persons of active reproductive age compared to those of early one. It is worth mentioning that the physical component scores in women of the basic group were slightly lower than in controls - "Role-Physical Functioning" score by $13.55 \%$, "General Health" - by $10.85 \%$. Statistically significant difference was found only between women of the II subgroup and controls in the "Physical Functioning" scores by $11.59 \%(P=0.039)$ and "General Health" - by $15.98 \%(P=0.026)$ lower.

Statistically significant and more pronounced decrease in quality of life was found in parameters of the psychological component. The "Vitality" and "Social functioning" scores was determined to be especially decreased by $16.51 \%$ $(P=0.021)$ and $23.12 \%(P<0.001)$, respectively, as compared to healthy women. The results of all scores were lower in persons of the II subgroup in comparison to I.

\section{Discussion}

PCOS is associated with decreased quality of life [4]. A number of pathogenetic mechanisms and pathological factors as well as clinical manifestations influence it. We determined more significant changes in psychological component of quality of life compared to physical one in PCOS patients, similar to other scientists $[5,9,10]$. Problems with self-esteem, self-perception and sexual dysfunction are usually associated with PCOS [11]. Results of our study have demonstrated that persons of active reproductive age face greater challenges with increased body weight, metabolic changes than women in early reproductive age. It is believed that obesity had an adverse impact on the psychological aspects of quality of life $[9,12,13]$. Besides this, desire for children, pregnancy and childbirth is far more common for older women. It is known, that women with metabolic syndrome and PCOS have problems with fertility, pregnancy 
course and adverse pregnancy outcomes [14,15]. Disorders of menstrual function together with infertility become not only medical problem for them but also psychological one that influences negatively their quality of life. So, nowadays medical aspects of PCOS are associated with psychological parameters of women. That is why such persons are in need of psychosomatic consultation $[1,4,16]$.

\section{Conclusions}

1. In women with PCOS, menstrual dysfunction, morphological changes in the ovaries, hormonal disorders are present. Metabolic disorders are more pronounced in patients of active reproductive age compared to early one $(P<0.05)$.

2. Decrease in quality of life is typical for women with PCOS. There is no significant difference in the physical component of quality of life between PCOS women of early reproductive age and controls. Though, the "Physical Functioning" and "General Health" scores are statistically significantly decreased in patients of active reproductive age compared to the healthy individuals.

3. However, the decrease in the psychological component of quality of life is typical for women with PCOS, especially for persons of active reproductive age compared to early one.

Prospects for further research. In the future, we will study the levels of depression and anxiety in women with PCOS.

Conflicts of interest: authors have no conflict of interest to declare. Конфиікт інтересів: віАсутній.

Information about authors:

Pakharenko L. V., MD, PhD, DSc, Associate Professor, Professor of the Department of Obstetrics and Gynecology, State Higher Educational Establishment "Ivano-Frankivsk National Medical University", Ukraine.

Vorobii V. D., MD, PhD, DSc, Associate Professor, Professor of the Department of Obstetrics and Gynecology, State Higher Educational Establishment "Ivano-Frankivsk National Medical University", Ukraine.

Kurtash N. Ya., MD, PhD, Associate Professor of the Department of Obstetrics and Gynecology, State Higher Educational Establish ment "Ivano-Frankivsk National Medical University", Ukraine. Perkhulyn O. M., MD, Assistant, Department of Obstetrics and Gynecology, State Higher Educational Establishment "IvanoFrankivsk National Medical University", Ukraine.

\section{Відомості про авторів:}

Пахаренко А. В., А-р меА. наук, Аоцент, професор каф. акушерства та гінекології, АВНЗ «вано-Франківський національний медичний університет", Україна.

Воробій В. А., А-р меА. наук, Аоцент, професор каф. акушерства та гінекології, АВНЗ «вано-Франківський національний медичний університет”, Україна.

Курташ Н. Я., канА. меА. наук, Аоцент каф. акушерства та гінекології, АВНЗ «вано-Франківський національний меАичний університет", Україна.

Перхулин О. М., асистент каф. акушерства та гінекології, АВН3 «вано-Франківський національний медичний університет, Україна.

\section{Сведения об авторах:}

Пахаренко А. В., А-р меА. наук, Аоцент, профессор каф. акушерства и гинекологии, ГВУЗ «Ивано-Франковский национальный медицинский университет", Украина.
Воробий В. А., А-р меА. наук, Аоцент, профессор каф. акушерства и гинекологии, гВУз “Ивано-Франковский национальный медицинский университет", Украина. Курташ Н. Я., канА. меА. наук, Аоцент каф. акушерства и гинекологии, ГВУЗ “Ивано-Франковский национальный медицинский университет", Украина.

Перхулин О. М., ассистент каф. акушерства и гинекологии, ГВУЗ “Ивано-Франковский национальный медицинский университет", Украина.

Надійшла Ао редакції / Received: 23.05.2018

Після Аоопрацювання / Revised: 01.06.2018

Прийнято Ао Аруку / Accepted: 04.06.2018

\section{References}

[1] Setji, T. L., \& Brown, A. J. (2014). Polycystic ovary syndrome: update on diagnosis and treatment. Am J Med, 127 (10), 912-919. doi: 10.1016/j. amjmed.2014.04.017.

[2] Escobar-Morreale, H. F. (2018). Polycystic ovary syndrome: definition, aetiology, diagnosis and treatment. Nat Rev Endocrinol, 14(5), 270-284. doi: 10.1038/nrendo.2018.24.

[3] Kakoly, N. S., Khomami, M. B., Joham, A. E., Cooray, S. D., Misso, M. L., Norman, R. J., et al. (2018). Ethnicity, obesity and the prevalence of impaired glucose tolerance and type 2 diabetes in PCOS: a systematic review and meta-regression. Hum Reprod Update., 24(4), 455-467. doi: 10.1093/humupd/dmy007.

[4] Böttch, B., Fessler, S., Friedl, F., Toth, B., Walter, M. H., Wildt, L., \& Riedl, D. (2017). Health-related quality of life in patients with polycystic ovary syndrome: validation of the German PCOSQ-G. Arch Gynecol Obstet, 297(4), 1027-1035. doi: 10.1007/s00404-017-4623-2.

[5] Borghi, L., Leone, D., Vegni, E., Galiano, V., Lepadatu, C., Sulpizio, P., \& Garzia, E. (2018). Psychological distress, anger and quality of life in polycystic ovary syndrome: associations with biochemical, phenotypical andsocio-demographic factors. J Psychosom Obstet Gynaecol, 39(2), 128-137. doi: 10.1080/0167482X.2017.1311319.

[6] Balikci, A., Erdem, M., Keskin, U., Bozkurt Zincir, S., Gülsün, M., Özçelik, F., et al. (2014). Depression, Anxiety, and Anger in Patients with Polycystic Ovary Syndrome. Noro Psikiyatr Ars, 51(4), 328-333. doi: 10.5152/npa.2014.6898.

[7] Khomami, M. B., Tehrani, F. R., Hashemi, S., Farahmand, M., \& Azizi, F. (2015). Of PCOS symptoms, hirsutism has the most significant impact on the quality of life of Iranian women. PLoS One, 10(4), e0123608. doi: 10.1371/journal.pone.0123608.

[8] Rotterdam ESHRE/ASRM-Sponsored PCOS Consensus Workshop Group. (2004). Revised 2003 consensus on diagnostic criteria and longterm health risks related to polycystic ovary syndrome. Fertil Steril, 81, 19-25. doi: https://doi.org/10.1016/j.fertnstert.2003.10.004

[9] Kaczmarek, C., Haller, D. M., \& Yaron, M. (2016). Health-Related Quality of Life in Adolescents and Young Adults with Polycystic Ovary Syndrome: A Systematic Review. J Pediatr Adolesc Gynecol, 29(6), 551-557. doi: 10.1016/j.jpag.2016.05.006

[10] ZareMobini, F., Kazemi, A., \& Farajzadegan, Z. (2018). A comprehensive mental health care program for women with polycystic ovary syndrome: protocol for a mixed methods study. Reprod Health, 15(1), 46. doi: 10.1186/s12978-018-0488-5.

[11] Bazarganipour, F., Ziaei, S., Montazeri, A., Foroozanfard, F., Kazemnejad, A., \& Faghihzadeh, S. (2014). Health-related quality of life in patients with polycystic ovary syndrome (PCOS): a model-based study of predictive factors. J Sex Med, 11(4), 1023-1032. doi: 10.1111/jsm.12405.

[12] Panico, A., Messina, G., Lupoli, G. A., Lupoli, R., Cacciapuoti, M., Moscatelli, F., et al. (2017). Quality of life in overweight (obese) and normal-weight women with polycystic ovary syndrome. Patient Prefer Adherence, 11, 423-429. doi: 10.2147/PPA.S119180.

[13] Shishehgar, F., Ramezani Tehrani, F., Mirmiran, P., Hajian, S., \& Baghestani, A. R. (2016). Comparison of the Association of Excess Weight on Health Related Quality of Life of Women with Polycystic Ovary Syndrome: An Age- and BMI-Matched Case Control Study. PLoS One, 11(10), e0162911. doi: 10.1371/journal.pone.0162911.

[14] Tziomalos, K., \& Dinas, K. (2018). Obesity and Outcome of Assisted Reproduction in Patients With Polycystic Ovary Syndrome. Front Endocrinol (Lausanne), 9, 149. doi: 10.3389/fendo.2018.00149.

[15] Palomba, S., Falbo, A., Daolio, J., Battaglia, F. A., \& Sala, G. B. (2018). Pregnancy complications in infertile patients with polycystic ovary syndrome: updated evidences. Minerva Ginecol, doi: 10.23736 S0026-4784.18.04230-2.

[16] Tan, J., Wang, Q. Y., Feng, G. M., Li, X. Y., \& Huang, W. (2017). Increased Risk of Psychiatric Disorders in Women with Polycystic Ovary Syndrome in Southwest China. Chin Med J (Engl), 130(3), 262-266. doi: 10.4103/0366-6999.198916. 